\title{
Fabrication of ceramic hollow fibre membranes from aluminium dross waste for water purification
}

\author{
Mohd Haiqal Abd Aziz, Mohd Hafiz Dzarfan Othman*, Ahmad Fauzi Ismail, Mukhlis Abdul \\ Rahman, Juhana Jaafar, Siti Khadijah Hubadillah, Tai Zhong Cheng
}

Advanced Membrane Technology Research Centre (AMTEC), Faculty of Chemical and Energy Engineering (FCEE), Universiti Teknologi Malaysia, 81310 UTM, Skudai, Johor, Malaysia.

* Corresponding author: hafiz@petroleum.utm.my

\section{Article history}

Received 5 May 2018

Revised 1 June 2018

Accepted 2 July 2018

Published Online 25 August 2019

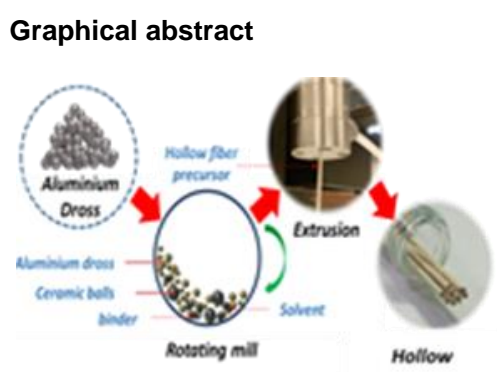

\begin{abstract}
In this study, alumina-spinel composite hollow fibre membranes were fabricated from abundantly available aluminium dross waste, which can be commonly obtained from aluminium-producing factory. The hollow fibre membranes were successfully fabricated by using a combine phase inversion method and sintering technique. The effects of sintering temperatures on morphology, mechanical strength, and permeability of the hollow fibre membranes were systematically investigated. X-ray fluorescence (XRF) was used to analyze the composition of the aluminium dross waste, while x-ray diffraction analysis (XRD) were further studied to characterize the major crystalline phase of the sintered hollow fibre membranes. An increase in sintering temperatures resulted in densification of hollow fibre membrane, consequently induced the flux reduction. The presence of spinel in microstructural of hollow fibre assisted in decreasing the sintering temperature. As comparison to pure alumina membrane counterparts, this alternative ceramic hollow fibre membrane exhibited a comparable mechanical strength of $78.3-155.1 \mathrm{MPa}$ with lower sintering temperatures ranging from $1350{ }^{\circ} \mathrm{C}$ to $1400{ }^{\circ} \mathrm{C}$ at ceramic loading of $40 \%$.
\end{abstract}

Keywords: Aluminium dross, ceramic hollow fibre membrane, alumina, spinel

(c) 2019 Penerbit UTM Press. All rights reserved

\section{INTRODUCTION}

Ceramic membranes have attracted wide attention in recent years as compared to polymeric membranes in the continuous effort for greater structural integrity of membrane. Polymeric membrane possesses several deficiencies when considering them for use in harsh environments such as high temperature, high acidity, or basic environment (Fung \& Wang, 2014). In contrast, metal oxides like alumina $\left(\mathrm{Al}_{2} \mathrm{O}_{3}\right)$, titania $\left(\mathrm{TiO}_{2}\right)$, and zirconia $\left(\mathrm{ZrO}_{2}\right)$ are the most preferable inorganic materials used for fabrication of ceramic membranes owing to better chemical and thermal resistivity with lower fouling propensity (Fung \& Wang, 2014; Li et al., 2015). Among all kinds of metal oxides, alumina is the most commonly used inorganic material for the fabrication of ceramic membrane, which is relatively expensive ( $\mathrm{Li}, 2007$ ) as cost around $\$ 500 / \mathrm{m}^{2}$ (Hubadillah et al., 2016). Therefore, some efforts have been made to fabricate ceramic membranes from low-cost materials that are easy to be processed, has good availability, and require low sintering temperature. To date, several successful syntheses have been reported in a number of studies using natural minerals and abundant inorganic waste to fabricate ceramic membranes. Some of the materials are bauxite ( $\mathrm{Li}$ et al., 2015)., rice husk ash (Hubadillah et al., 2016), Tunisian clay (Khemakhem \& Amar, 2011), Cameroonian clay (Belibi et al., 2015), and meta-kaolin (Hubadillah et al., 2016). These materials are mostly in the combination of two major mineral oxides comprising of $\mathrm{Al}_{2} \mathrm{O}_{3}$ and $\mathrm{SiO}_{2}$ along with some minor composition of minor oxides like $\mathrm{TiO}_{2}$ and $\mathrm{Fe}_{2} \mathrm{O}_{3}$. Currently, there are very limited number of studies on the utilization of the abundant inorganic industrial-byproduct. The unique properties and characteristics of aluminium dross waste, a by-product of aluminium smelting industries such as high composition of alumina, make this material an attractive option.

Aluminium dross is a complex oxidic material and it is formed during aluminium melting by oxidation of the metals when it comes into contact with air. The produced byproduct accumulates on the surface of the melting aluminium which consists of inorganic substances with a high amount of oxides (Adeosun, Sekunowo, Taiwo, Ayoola, \& Machado, 2014). Primarily, this waste is produced by aluminium industry and it is in the form of solids and dark-grey in color. It is also irregular in shape, containing lumps, and granules during the aluminium burn off in a furnace (Reddy \& Neeraja, 2016). The aluminium dross clumps contains a high amount of metals with a few amount of oxides while fine aluminium dross has an extremely high amount of oxides and salts (Adeosun et al., 2014). The main constituents of aluminium dross are $\mathrm{Al}_{2} \mathrm{O}_{3}, \mathrm{SiO}_{2}$, and $\mathrm{MgO}$ of which the amount of alumina content is in the range of 50\% to $75 \%$ (Dash et al., 2008; Li, Zhang, \& Yang, 2014). Realizing the potential of this alumina-rich material, some study has looked into the utilization of aluminium dross in ceramic products, cement, nonferrous metals, and even in some extent to nuclear engineering and space technologies $(\mathrm{Li}$ et al., 2014).

The amount of aluminium dross generated per metric tons of molten aluminium is approximately $5-2 \mathrm{~kg}$ (How et al., 2016). In the US alone, a rough estimate shows that aluminium industry produces nearly five million tons of this waste annually (How et al., 2016). To make things 
worse, millions tons of this waste ends up in landfill sites, which causes serious health and environmental damage (Reddy \& Neeraja, 2016). Landfilling of aluminium dross is not ecologically fair and may cause environmental damage. In Malaysia, aluminium dross has been classified as a scheduled waste. Such waste must be collected, treated, and disposed off in a proper and safe manner. In addition, disposal of this waste is cost-intensive where the cost charged is $\$ 490$ per ton by the local authorities (Muslim et al., 2009). The high cost of fee associated with this waste could be a burden to aluminium manufacturing companies which may result into illegal dumping of this aluminium dross waste to a secluded area by irresponsible parties. Ideally, this schedule waste could be processed as an industrial byproduct for development of ceramic membrane with potential applications.

In this study, the aluminium dross residue from an aluminium industry have been utilized to fabricate a product of value, in particular ceramic hollow fibre membrane. A successful transition of this material to hollow fibre was further studied based on the effect of sintering temperature on the morphology and microstructure, mechanical properties and permeability of the as-prepared ceramic hollow fibre membranes.

\section{EXPERIMENTAL}

\section{Materials}

Aluminium dross was obtained from an aluminium smelting company located at Pasir Gudang (Johor, Malaysia). The sample was dry, bulk solid, and dark grey in color that was composed of lumps and fine particles. The sample was sieved to less than $70 \mu \mathrm{m}$ to obtain powdery aluminium dross which is rich in oxides compounds whilst removing most of the metal found in the original material. Arlacel (Polyethyleneglycol 30 Dipolyhydroxystrearate, CRODA) was used as a dispersant of the ceramic powder, 1-Methyl-2-pyrrolidon (NMP, MERCK) solution as a solvent, and Polyethersulfone (PESf) (Radel A300, Ameco Performance, USA) was used as a binder.

\section{Preparation of ceramic hollow fibre membranes}

The combined phase inversion and sintering technique was used to fabricate hollow fibre membranes synthesis from aluminium dross. Prior to the fabrication of hollow fibre, the aluminium dross was milled in a planetary ball mill for $24 \mathrm{~h}$ and sieved to get powder size of less than $36 \mu \mathrm{m}$. Ceramic suspension was prepared by mixing $1 \mathrm{wt} \%$ of Arlacel and $40 \mathrm{wt} . \%$ of aluminium dross powder in $53.3 \mathrm{wt} \%$ of NMP, as shown in Table 1. The mixture of ceramic powder, solvent and dispersant was milled for $48 \mathrm{~h}$ and later PESf binder was added and further milled for another a $48 \mathrm{~h}$ period. The ceramic suspension was degassed in a vacuum chamber for $1 \mathrm{~h}$ to eliminate any air bubbles entrapped in the ceramic suspension. The degassed suspension was then transferred to a syringe and extruded through a spinneret with outer and inner diameter of $2.5 \mathrm{~mm}$ and $5 \mathrm{~mm}$ at a constant flowrate of $9 \mathrm{ml} / \mathrm{min}$ with the bore fluid (tap water) of $10 \mathrm{ml} / \mathrm{min}$, which fabrication details is listed in Table 2. The extrusion of hollow fibre precursors with $5 \mathrm{~cm}$ of air gap were conducted directly into tap water and immersion was continued for $24 \mathrm{~h}$ to ensure a completion process of phase inversion. The precursors were cut $(20 \mathrm{~cm})$ and dried in the open air at ambient temperature. The as-prepared precursor was then subjected to sintering in a tube furnace (Magna Value, XY-1700). Initially, the precursors were sintered to $600^{\circ} \mathrm{C}$ for $2 \mathrm{~h}$ at a rate of $2{ }^{\circ} \mathrm{C} / \mathrm{min}$ to allow a complete removal of polymer binder followed by increasing to target temperatures of $1250{ }^{\circ} \mathrm{C}$ to $1400^{\circ} \mathrm{C}$ for $5 \mathrm{~h}$ at a rate of $5{ }^{\circ} \mathrm{C} / \mathrm{min}$ to consolidate the ceramic membrane. The membranes were then cooled down to room temperature. Overview of fabrication procedure of hollow fibre precursors is shown in Fig. 1.
Table 1 Composition of ceramic suspension.

\begin{tabular}{lc}
\hline \multicolumn{1}{c}{ Component } & Mass $\%$ \\
\hline Aluminium dross powder & 40 \\
PESf & 5.71 \\
NMP & 53.29 \\
Arlacel & 1 \\
\hline
\end{tabular}

Table 2 Hollow fibre fabrication conditions.

\begin{tabular}{lc}
\hline Fabrication parameters & \\
\hline Bore fluids $(\mathrm{ml} / \mathrm{min})$ & 10 \\
Extrusion speed $(\mathrm{ml} / \mathrm{min})$ & 9 \\
Air gap $(\mathrm{m})$ & 0.05 \\
Sintering temperature $\left({ }^{\circ} \mathrm{C}\right)$ & $1250-1400$ \\
\hline
\end{tabular}

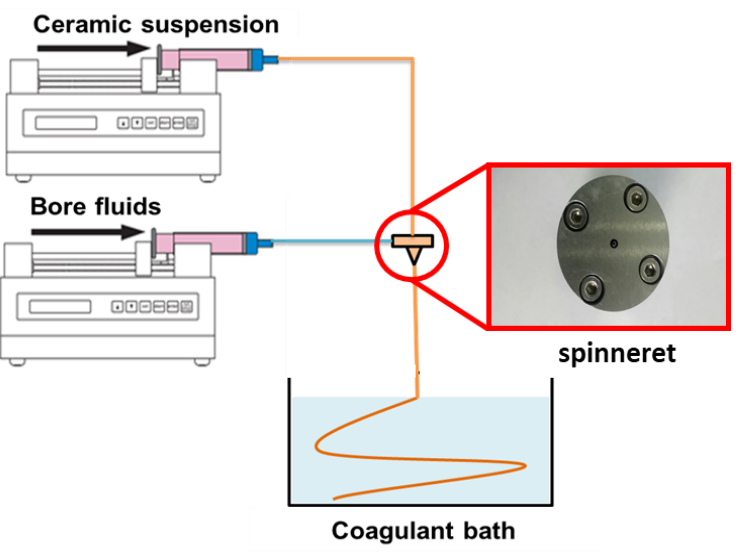

Fig. 1 Schematic diagram for preparation of hollow fibre percursor through extrusion.

\section{Charactherization of materials}

Chemical composition of ceramic powder was examined through $\mathrm{x}$-ray fluorescence (XRF) (Rigaku, model NEXCG EDXRF). The sample was placed in a $32 \mathrm{~mm}$ sample cup with a prolene thin-film sample support. The quantitative elemental analysis was carried out at ambient temperature of $18^{\circ} \mathrm{C}$ to $28^{\circ} \mathrm{C}$ with relative humidity of less than $75 \%$.

X-ray diffraction (XRD) analysis of raw and sintered ceramic hollow fibre was performed by using Rigaku Smartlab, a powder diffractometer instrument equipped with copper anode. The powder sample was placed in a silicon glass samples holder. The diffraction patterns were produced by generating beta-filtered $\mathrm{CuKa}$ radiation at $40 \mathrm{kV}$. The scanning range of $2 \theta$ from $3^{\circ}$ to $100^{\circ}$ was applied with scanning resolution of $0.02^{\circ}$

High-resolution image of the morphologies and microstructures of the hollow fibre was taken using a scanning electron microscope, (SEM) (TM 3000, Hitachi). The mechanical properties of the ceramic hollow fibre membranes were tested using 3-point bending experiment with $1 \mathrm{kN}$ of load cell applied on the hollow fibre. The bending strengths were calculated using the following equation.

$$
\sigma_{F}=8 F L D_{o} / \pi\left(D_{o}{ }^{4}-D_{i}{ }^{4}\right)
$$

where, $\mathrm{F}$ is the force at which the fracture of specimen takes place, $\mathrm{L}$ is the distance between the two rollers, and Do and Di are the outer and inner diameter of membranes, respectively.

The mercury intrusion porosimetry (MIP) technique (micromeritics Autopore V) was employed to obtain average pore diameter and tortuosity factor of the membranes. The porosity of the prepared hollow fiber membranes was also analyzed by image tool ImageJ as described elsewhere (Li et al., 2015). The porosity was measured by calculating the percentage of red pixels, which represent the pores to total pixels across the membrane surface.

Water flux testing of ceramic hollow fibre membranes were tested by using cross flow filtration systems. Prior to that, the membrane was potted in adapter and sealed one end of the hollow fibre using epoxy resin. Water feed was applied across the membrane at positive pressure 
difference of 1 bar and the weight of permeate was recorded after $2 \mathrm{~h}$ for every hollow fibre samples.

\section{RESULTS AND DISCUSSION}

\section{Chemical composition}

$\mathrm{XRF}$ analysis found that the main oxide compounds in the raw powdery aluminium dross were $\mathrm{Al}_{2} \mathrm{O}_{3}$ (83.2 wt.\%), $\mathrm{Fe}_{2} \mathrm{O}_{3}$ (5.4 wt.\%), $\mathrm{SiO}_{2}$ (3.5 wt.\%), $\mathrm{MgO}$ (2.8 wt.\%), $\mathrm{CaO}$ (2.4 wt.\%), $\mathrm{K}_{2} \mathrm{O}$ (1.4 wt.\%), and $\mathrm{TiO}_{2}$ (1.3 wt.\%). The composition ranges of this materials is in approximate agreement with previous studies (How et al., 2016)

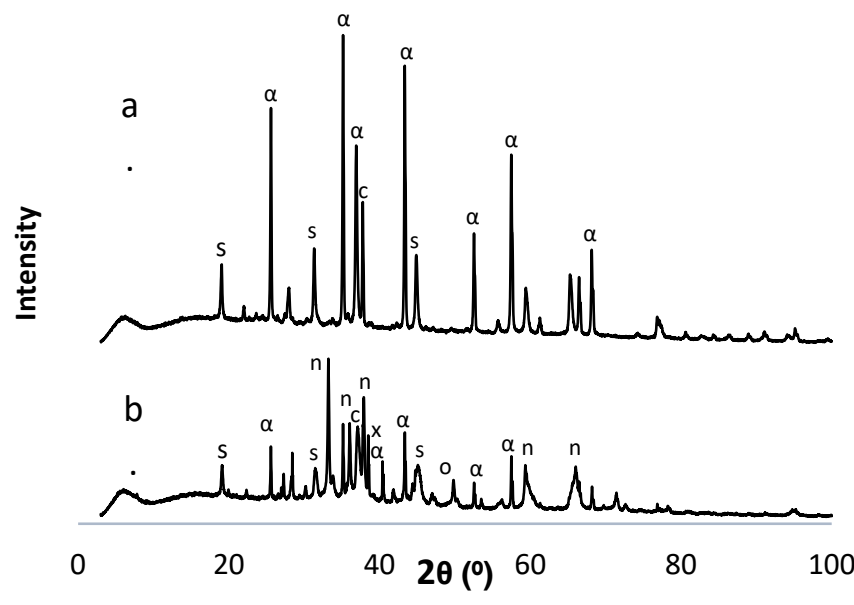

Fig. 2 XRD analysis of (a) Hollow fibre membrane sintered at $1350^{\circ} \mathrm{C}(\mathrm{b})$ raw aluminium dross $\left(\alpha-\mathrm{Al}_{2} \mathrm{O}_{3}, \mathrm{~s}-\mathrm{MgO} \cdot \mathrm{Al}_{2} \mathrm{O}_{3}, \mathrm{c}-\mathrm{Al}_{4} \mathrm{C}_{3}, \mathrm{n}-\mathrm{AIN}, \mathrm{o}-\mathrm{Al}(\mathrm{OH})_{3} \mathrm{X}-\right.$ Al).

Table 3 Crystalline phase analysis by XRD using reference intensity ratio (RIR) method.

\begin{tabular}{lcc}
\hline Component & $\begin{array}{c}\text { Raw aluminium } \\
\text { dross (wt.\%) }\end{array}$ & $\begin{array}{c}\text { Hollow fibre } \\
\text { membrane (wt\%) }\end{array}$ \\
\hline $\mathrm{AlN}$ & 30 & 0.01 \\
$\mathrm{Al}_{2} \mathrm{O}_{3}$ & 23 & 74 \\
$\mathrm{Al}(\mathrm{OH})_{3}$ & 4.6 & - \\
$\mathrm{MgO} \mathrm{Al}_{2} \mathrm{O}_{3}$ & 41 & 24 \\
$\mathrm{Al}$ & 0.1 & - \\
$\mathrm{Al}_{4} \mathrm{C}_{3}$ & 0.1 & 1.6 \\
\hline
\end{tabular}

(Reddy \& Neeraja, 2016).

Quantitative phase analysis on raw aluminium dross and hollow fiber membrane by XRD techniques using reference intensity ratio (RIR) method is summarized in Table 3. Fig. 2(b) shows the crystalline phases of raw aluminium dross that comprised of a mixture of watersoluble compounds such as aluminium nitride (AlN), aluminium carbide $\left(\mathrm{Al}_{4} \mathrm{C}_{3}\right)$, non-water soluble compounds principally made up of alumina $\left(\mathrm{Al}_{2} \mathrm{O}_{3}\right)$, spinel $\left(\mathrm{MgO} . \mathrm{Al}_{2} \mathrm{O}_{3}\right)$, hydrated alumina $\mathrm{Al}(\mathrm{OH})_{3}$, and metal compound of aluminium $(\mathrm{Al})$. Analysis of the crystalline phase of the ceramic hollow fibre membrane is shown in Fig. 2(a). As the hollow fibre was sintered at $1350{ }^{\circ} \mathrm{C}$, aluminium nitride, hydrated alumina, and small traces of aluminium metal decompose significantly of more than 99.9 wt.\% of the initial weight while the $\mathrm{Al}_{2} \mathrm{O}_{3}$ content is increased with the increasing of calcination temperature. This is believed to occur due to solid-state reaction which takes place in an oxidizing atmosphere of furnace, resulting to reduction of those compounds during calcination of membrane precursor, and consequently converted into $\mathrm{Al}_{2} \mathrm{O}_{3}$ (Lopez et al., 1994). XRD results identified a small trace of $\mathrm{Al}_{4} \mathrm{C}_{3}$ in raw aluminium dross and appears to have higher in weight after calcination process. The results suggested an increase of $\mathrm{Al}_{4} \mathrm{C}_{3}$ was likely to be due to reaction between alumina and carbon in the furnace during solid-state sintering. The sintered aluminium dross hollow fibre comprised of a mixture of corrundum, spinnel, and together with smaller traces of aluminium carbide and nitride. Evidence for this was provided by XRD analysis as shown in Table 3.

\section{Morphology and microstructure of aluminium dross hollow fibre}

Fig. 3(a) represents a digital image of hollow fibre membranes with an average inner diameter and outer diameter of 0.67 and $1.0 \mathrm{~mm}$, respectively, and appeared to be pale-yellow in color after the final sintering. The yellowish appearance is thought to be due to a small amount of $\mathrm{Fe}_{2} \mathrm{O}_{3}(4.68 \%)$ presence in aluminium dross powder and this is in agreement with the result reported by other researchers (Zhu, Chen, Dong, Tang, \& Huang, 2016). The membranes shown in Fig. 3(a) were prepared
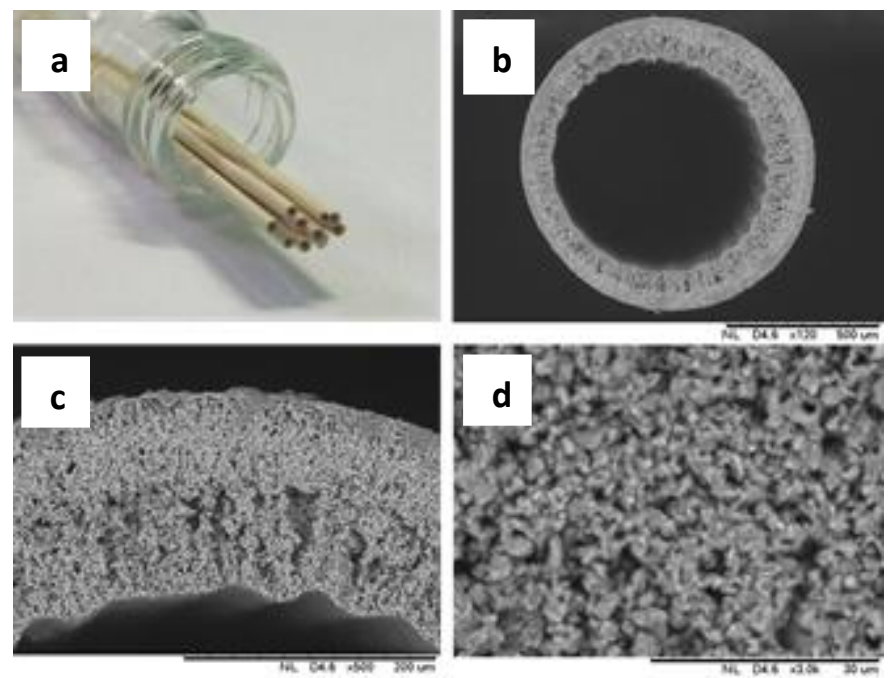

Fig. 3 (a) Photographic image, (b) SEM image of whole view, (c) SEM image of cross-sectional view and (d) SEM images of sponge-like region of low-cost hollow fibre membrane.

from $40 \%$ of aluminium dross loading and sintered at $1350^{\circ} \mathrm{C}$. At higher magnification of the cross sectional of the as-prepared membrane are shown in Fig. 3(b), 3@), and 3(d). Macrovoids near the inner edge of fibre wall and dense sponge-like structure at the outer edge of fibre wall could be observed. The ratio of the thickness of macrovoids and dense layer in overall cross section were approximately $1: 1$.

The formation of macrovoids were originated at the inner surface, which is believed could be resulted from interfacial instabilities between two fluids of solvent and non-solvent during phase inversion process. This mechanism can be interpreted by Rayleigh-Taylor hydrodynamic instabilities (RTI) owing to different density at the interface which result in interpenetration from lighter coagulant phase towards the heavier solutions (Lee et al., 2015). The existence of 5-cm air-gap causes an increase in local viscosity at the outer region as a result of simultaneous evaporation of solvent to the atmosphere (Kingsbury \& Li, 2009). Consequently, inhibiting the growth of macrovoid channels and initiating the formation of sponge-like region, dense structure at the outer surface. The acceleration of the interpenetration terminated because of the ceramic particles were tightly packed together and immobilised by precipitated polymer. The combination of both structures across the entire hollow fibre membrane play important roles between permeability and selectivity in water purifications. The dense structure at the outer region of the membrane provides mechanical strength and enhances selectivity while macrovoids region improves water permeability (Zhu et al., 2016).

\section{Effect of sintering temperatures}

In order to find a proper sintering temperature for the hollow fibre, the sintering process was carried out at higher temperature than $1250^{\circ} \mathrm{C}$ and the microstructures of hollow fibre were analysed by SEM. Fig. 4 illustrates the cross-sectional SEM images of ceramic hollow fibre membranes sintered at various temperatures from $1250{ }^{\circ} \mathrm{C}$ to $1400{ }^{\circ} \mathrm{C}$. At temperature lower than $1250^{\circ} \mathrm{C}$, it was found that the membrane was too brittle while when the membrane was sintered at temperature of $1400{ }^{\circ} \mathrm{C}$, a denser membrane with a lower porosity and pore size were formed as shown in figure 4(d) and 4(d1). 
At higher magnification, further increase of sintering temperatures result in individual grain move toward one another and enhanced densification as shown in Fig. 4(a1-d1). However, the formation of neck growth between grain boundries has resulted in decrease of porosity, a clear relation between solid sintering, and densification.

As shown in Fig. 5, dual microstructure of needle and flake shapes of alumina-spinel composite is clearly seen in cross sectional view of hollow fibre. However, this structure is not noticeable when the sintering temperature is more than $1300^{\circ} \mathrm{C}$ due to the bonding formation between the particles during neck growth and grain of much larger size appear.
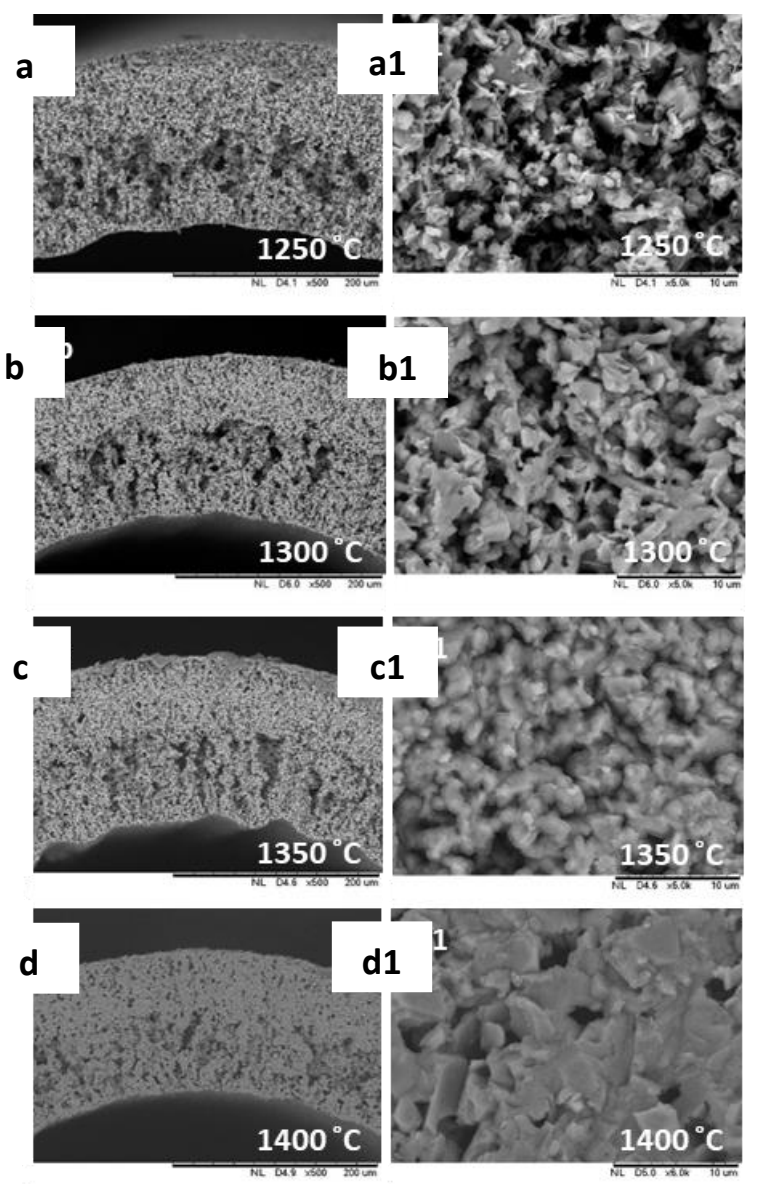

Fig. 4 Micrographs images of cross-sectional view and inner surface of hollow fibre membranes at various sintering temperatures; $1250{ }^{\circ} \mathrm{C}(\mathrm{a}$, a1), $1300{ }^{\circ} \mathrm{C}$ (b, b1), $1350^{\circ} \mathrm{C}$ (c, c1), $1400^{\circ} \mathrm{C}$ (d, d1)

The hollow fibre was shrunk from $7.5 \%$ to $26.6 \%$ as sintering progressed from $1250{ }^{\circ} \mathrm{C}$ to $1400{ }^{\circ} \mathrm{C}$. Membrane shrinkage can again be explained by the rapid neck growth during solid state sintering and lead to increase in grain size and pore closing. As in Fig. 4(a1), the microstructure appears to be individual irregular shapes and the grains of much larger size appear rapidly as sintering temperature progress to higher temperatures. As a result, densification and shrinkage of overall morphology occurs, followed by the disappearance of pores (Fig. 4(a1d1)).

\section{Mechanical properties}

The results for mechanical properties as a function of sintering temperatures for the hollow fibre membranes are depicted in Fig. 6. The mechanical properties of each of the hollow fibre was calculated according to equation 1. It is apparent that the structural integrity of the hollow fibre increased with increasing the sintering temperature. The mechanical properties of the hollow fibre membrane were ranging from 78.3 $\mathrm{MPa}$ to $155.1 \mathrm{MPa}$ with sintering process at $1350^{\circ} \mathrm{C}-1400^{\circ} \mathrm{C}$. As discussed earlier, the increase of the mechanical strength could be related to consolidation of hollow fibre due to neck growth between the particles, consequently forming a strong bond between them ( $\mathrm{Li}$ et al., 2015).
It is worth to mention that the ceramic hollow fibre membranes fabricated from pure aluminia powder require higher sintering temperature of more than $1500{ }^{\circ} \mathrm{C}$. However, in this study, the growth of grains can be clearly seen at the temperature of $1300{ }^{\circ} \mathrm{C}$ and forming a compact interlocking structure with larger size when sintered beyond $1300{ }^{\circ} \mathrm{C}$.

It is noted that, the presence of spinel in the aluminium dross has a strong influence on the structural integrity of the hollow fibre membranes. The presence of $\mathrm{Mg}$ ions in alumina-spinel composite hollow fibre improve hardness by pinning the grain boundries through grain boundary diffusion during sintering process (Dadkhah, Saboori, $\&$ Jafari, 2014). As a result, a dense microstructure of hollow fibre was obtained. This behaviors of alumina-spinel composites is in agreement with the result reported by Yalamac (2014).

Compared to the previous study, a mechanical strength of 14.4 to $38.1 \mathrm{MPa}$ were obtained for alumina hollow fibre membrane respectively sintered at $1500-1600{ }^{\circ} \mathrm{C}$ and 100 to $180 \mathrm{MPa}$ for bauxite hollow fibre membranes by sintering at $1300-1350{ }^{\circ} \mathrm{C}$ in which, both prepared from the same ceramic loading of $45 \%$ (Li et al., 2015). Thus, the alumina-spinel composite hollow fibre membrane prepared from aluminium dross waste shows a comparable mechanical strength at lower ceramic loading, $40 \mathrm{wt} \%$ and sintering temperatures ranging from 1350 to $1400{ }^{\circ} \mathrm{C}$.

\section{Permeability}

The pure water permeation plot of the hollow fibre membrane with sintering at different temperatures is presented in Fig. 7. It can be seen that the water permeability reduced with increasing temperature. This result is believed to have resulted from the pore shrinkage as sintering progress to high temperature as clearly agreed with morphologies and microstructures in Fig. 4(a1-d1). The corresponding inner surface porosity measured via ImageJ sofware indicates that increasing sintering temperature from 1250 to $1400{ }^{\circ} \mathrm{C}$ leads to decrease of porosity from $52.6 \%$ to $30.3 \%$ as shown in Fig. 8 .
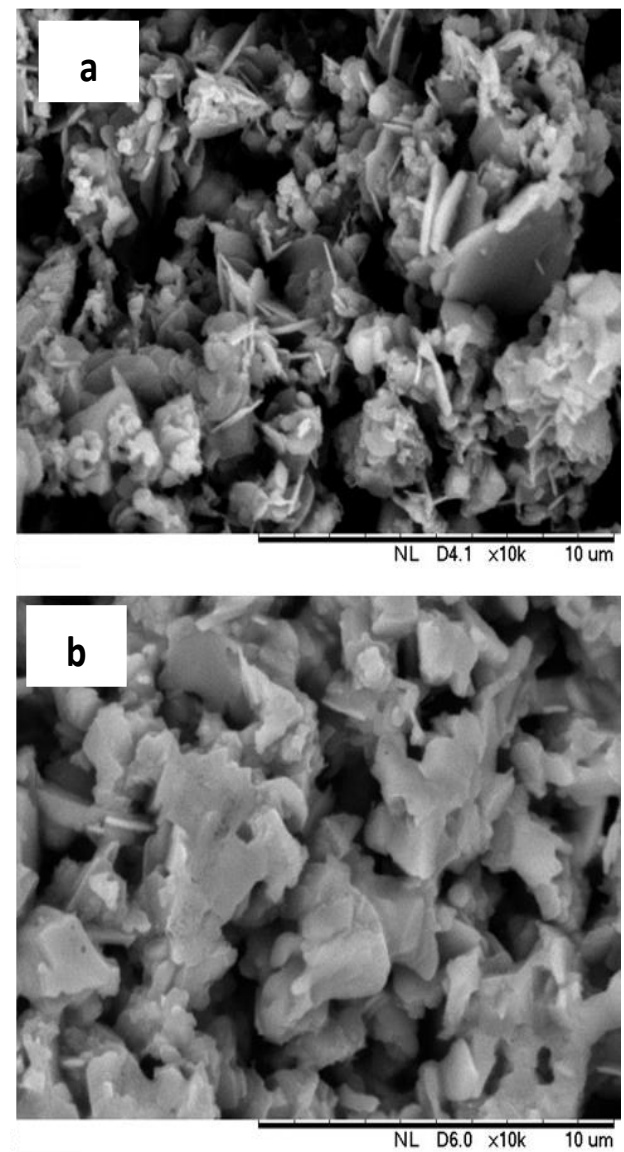

Fig. 5 High magnificant SEM micrographs of the microstructure of the hollow fibre sintered at (a) $1250^{\circ} \mathrm{C}$ (b) $1300^{\circ} \mathrm{C}$ 


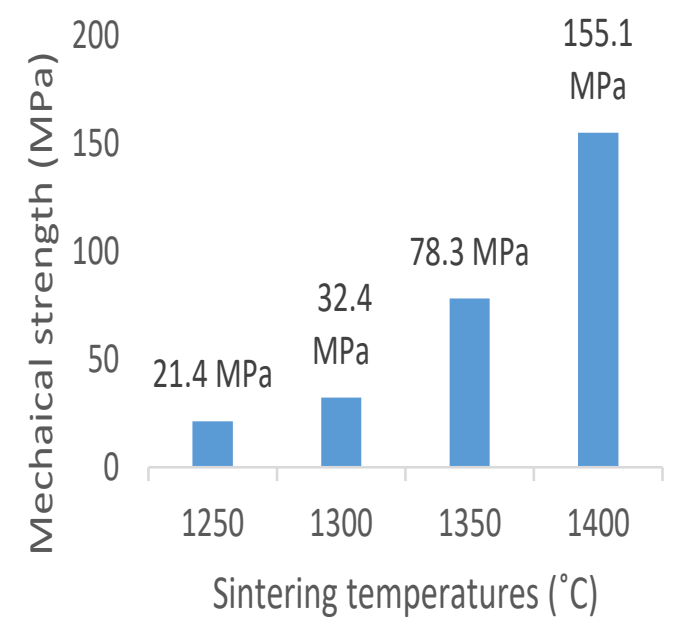

Fig. 6 Mechanical properties with different sintering temperatures from $1250{ }^{\circ} \mathrm{C}$ to $1400^{\circ} \mathrm{C}$

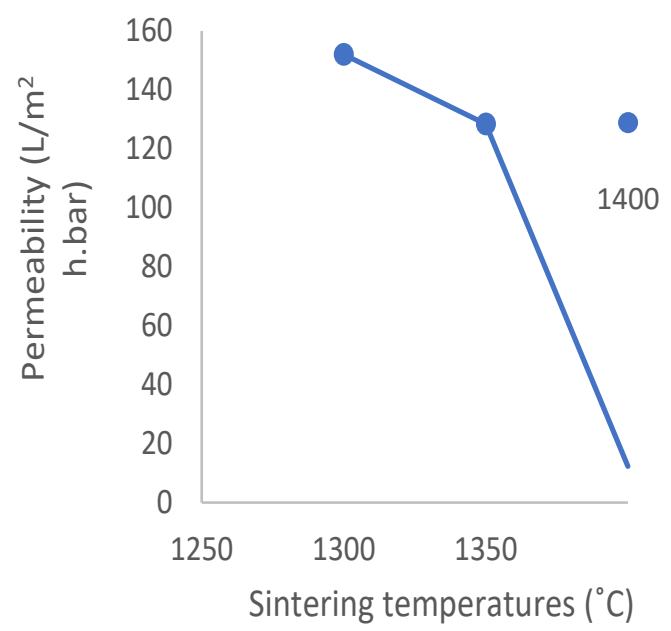

Fig. 7 Permeability of water with different sintering temperatures from $1250^{\circ} \mathrm{C}$ to $1400^{\circ} \mathrm{C}$

It is apparent that increase in sintering temperature induced a decline of the porosity consequently the measured water flux. Permeability of the hollow fibre membranes were ranging from 129 to $152 \mathrm{~L} / \mathrm{m}^{2} \mathrm{~h}$.bar at sintering temperature between $1300-1350{ }^{\circ} \mathrm{C}$ with porosity of $48.4 \%$ and $44.6 \%$. Hollow fibre membranes sintered at below $1250{ }^{\circ} \mathrm{C}$ were too fragile when subjected to positive pressure of water feed (1bar) as the membranes would begin to break down therefore, permeability of the hollow fibre could not be measured. In this preliminary characterization, the hollow fibre sintered at $1350{ }^{\circ} \mathrm{C}$ combine a high strength of $78.3 \mathrm{MPa}$ with large pure water permeance of $129 \mathrm{~L} / \mathrm{m}^{2} \mathrm{~h}$.bar. Mean pore diameter and tortuosity factor of $0.71 \mu \mathrm{m}$ and 2.1 was found for fiber sintered at $1350{ }^{\circ} \mathrm{C}$. The hollow fibre membranes sintered at $1400{ }^{\circ} \mathrm{C}$ onwards were too dense, giving a dramatic decline in pure water permeability of less than 12.3 L/m2h.bar.

\section{CONCLUSION}

This work was devoted to study the feasibility of aluminium dross waste to be utilized for fabrication of ceramic hollow fibre membranes. This was performed by investigating the appropriate sintering temperatures of the membrane. For the effect of sintering temperature on the alumina-spinel composite hollow fibre membrane, the finding

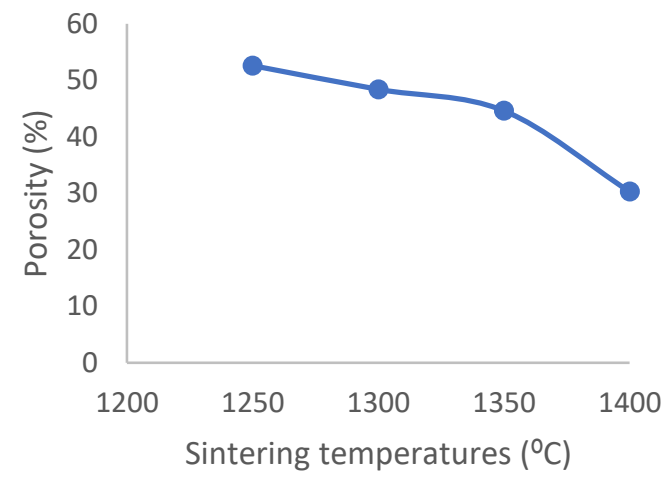

Fig. 8 inner surface porosity at different sintering temperatures from 1250 ${ }^{\circ} \mathrm{C}$ to $1400^{\circ} \mathrm{C}$.

suggested that the optimum condition was at $1350{ }^{\circ} \mathrm{C}$ with pure water permeability of $129 \mathrm{~L} / \mathrm{m}^{2} \mathrm{~h}$.bar and mechanical strength of $78.3 \mathrm{MPa}$

Overall, the emergence of cost-effective alumina-spinel composite hollow fibre membranes prepared from aluminium dross waste could be a very competitive candidate for membrane-based treatment. Besides, this finding is expected to provide opportunities for alternative alumina-spinel based hollow fibre membranes from aluminium dross waste and its utilization in such manner will be economical to aluminium manufacturing industries by reducing the cost of disposal and will also lead to less environmental problems.

\section{ACKNOWLEDGEMENT}

The authors gratefully acknowledge the financial support from the Ministry of Education Malaysia under the Higher Institution Centre of Excellence Scheme (Project Number: R.J090301.7846.4J192), and also Universiti Teknologi Malaysia under the Transdisciplinary Research Grant (Project number: Q.J130000.3509.05G75), Malaysia Research University Network (MRUN) Grant (Project number: R.J130000.7809.4L867), and UTM Fund (Project number: R.J130000.7746.4J309).

\section{REFERENCES}

Adeosun, S. O., Sekunowo, O. I., Taiwo, O. O., Ayoola, W. A., Machado, A. (2014). Physical and mechanical properties of aluminum dross. Advances in Materials, 3(2), 6-10.

Belibi Belibi, P., Nguemtchouin, M. M. G., Rivallin, M., Ndi Nsami, J., Sieliechi, J., Cerneaux, S., ... Cretin, M. (2015). Microfiltration ceramic membranes from local Cameroonian clay applicable to water treatment. Ceramics International, 41(2), 2752-2759.

Dadkhah, M., Saboori, A., Jafari, M. (2014). Investigating the physical properties of sintered alumina in the presence of $\mathrm{MgO}$ nanopowder. Journal of Materials, 1-7.

Dash, B., Das, B. R., Tripathy, B. C., Bhattacharya, I. N., Das, S. C. (2008). Acid dissolution of alumina from waste aluminium dross. Hydrometallurgy, 92(1-2), 48-53.

Fung, Y. L. E., Wang, H. (2014). Nickel aluminate spinel reinforced ceramic hollow fibre membrane. Journal of Membrane Science, 450, 418-424.

How, L. F., Islam, A., Jaafar, M. S., Taufiq-Yap, Y. H. (2016). Extraction and characterization of $\gamma$-alumina from waste aluminium dross. Waste and Biomass Valorization, 2-8.

Hubadillah, S. K., Dzarfan Othman, M. H., Harun, Z., Ismail, A. F., Iwamoto, Y., Honda, S., ... Mohd Sokri, M. N. (2016). Effect of fabrication parameters on physical properties of metakaolin-based ceramic hollow fibre membrane (CHFM). Ceramics International, 42(14), 15547-15558.

Hubadillah, S. K., Harun, Z., Othman, M. H. D., Ismail, A. F., Salleh, W. N. W., Basri, H., ... Gani, P. (2016). Preparation and characterization of low cost porous ceramic membrane support from kaolin using phase inversion/sintering technique for gas separation: Effect of kaolin content and non-solvent coagulant bath. Chemical Engineering Research and Design, 112, 24-35.

Hubadillah, S. K., Othman, M. H. D., Harun, Z., Ismail, A. F., Rahman, M. A., Jaafar, J. (2016). A novel green ceramic hollow fiber membrane (CHFM) derived from rice husk ash as combined adsorbent-separator for efficient heavy metals removal. Ceramics International, 43, 4716-4720. 
Khemakhem, S., Amar, R. Ben. (2011). Grafting of fluoroalkylsilanes on microfiltration Tunisian clay membrane. Ceramics International, 37(8), 3323-3328.

Kingsbury, B. F. K., Li, K. (2009). A morphological study of ceramic hollow fibre membranes. Journal of Membrane Science, 328(1-2), 134-140.

Li, A., Zhang, H., Yang, H. (2014). Evaluation of aluminum dross as raw material for high-alumina refractory. Ceramics International, 40(8 PART A), $12585-12590$

Li, K. (2007). Ceramic Membranes and Membrane Processes. Ceramic Membranes for Separation and Reaction. John Wiley \& Sons, Ltd, 1-20.

Li, L., Chen, M., Dong, Y., Dong, X., Cerneaux, S., Hampshire, S., ... Liu, J. (2015). A low-cost alumina-mullite composite hollow fiber ceramic membrane fabricated via phase-inversion and sintering method. Journal of the European Ceramic Society, 36(8), 2057-2066.

Lopez, F. A., Sainz, E., Formoso, A., Alfaro, I. (1994). Recovery of alumina from salt slags in aluminium remelting. Canadian Metallurgical Quarterly, 33(1), 29-33.

Muslim, M., Paulus, Wi., Yusoff, M. (2009). A Waste to wealth study on converting aluminium dross schedule waste into $\gamma$ and $\alpha$ Alumina. Recent Advances in Enviroment, Ecosystems and Development, 3, 17-21.

Reddy, M. S., Neeraja, D. (2016). Mechanical and durability aspects of concrete incorporating secondary aluminium slag. Resource-Efficient Technologies, 2(4), 225-232.

Yalamaç, E. (2014). Effect of spinel addition on the sintering behavior and microstructure of alumina-spinel ceramics. Ceramics - Silikaty, 58(4), 314319.

Zhu, L., Chen, M., Dong, Y., Tang, C. Y., Huang, A. (2016). A low-cost mullitetitania composite ceramic hollow fi ber micro fi ltration membrane for highly ef fi cient separation of oil-in- water emulsion, 90, 277-285. 